\title{
Bel ağrısının önemli bir sebebi: lomber disk hernisi
}

\author{
As a common cause of back pain: lumbar disc herniation
}

\author{
Seçkin Sarı ${ }^{1}$, Mehmet Aydoğan² \\ ${ }^{1}$ Memorial Hizmet Hastanesi, Bahçelievler, İstanbul \\ ${ }^{2}$ Bosphorus Spine Center, Nişantaşı Ortopedi Merkezi, İstanbul
}

\begin{abstract}
Lomber disk hernisi, toplumda sık görülen ve iş gücü kaybına neden olan bel ağrısı nedenleri arasında üst sıralarda yer almaktadır. Fıtıklaşan nükleusun etkilediği sinir köküne bağlı radiküler semptomlar verir. Lomber disk hernisi tanısı, radyolojik tetkiklerle desteklenen klinik semptomlar ve bulgular ışığında konur. Erken dönemde cerrahi tedavi sonuçları konservatif tedaviye göre belirgin olarak üstünse de, geç dönemde olumlu sonuçlar birbirine yaklaşır. Cerrahi veya konservatif tedavi seçenekleri, her hasta için irdelenmeli ve hastaya en uygun tedavi yöntemi bulunmalıdır.
\end{abstract}

Anahtar sözcükler: lomber disk hernisi; bel ağrısı; diskektomi

B el ağrısı, toplumda sık görülen ve iş gücü kaybına neden olan bir problemdir. Hayat boyu prevalansı \%80'lere ulaşmakta ve yetişkin nüfusta yıllık hastane başvuru oranları \%15'i bulmaktadır. ${ }^{[1,2]}$ Bel bölgesinde ağrı tüm anatomik yapılardan kaynaklanabildiği için, hem doktor hem hasta tarafından iyi lokalize edilememektedir. ${ }^{[3]}$

Klinik çalışmalar, bel ağrısının kaynağının \%39'lara varan oranda intervertebral disk patolojilerine bağlı olduğu göstermektedir. İntervertebral disk patolojileri alt grupları göz önüne alındığında, lomber disk hernisi ve dejeneratif disk hastalığı başı çekmektedir. ${ }^{[3]}$

Lomber disk hernisi, başlangıçta artan bel ağrısını takiben, sıklıkla ani gelişen kalça ve bacak ağrısı ile belirti veren, herniye olmuş nükleus pulpozus (nucleus pulposus) patolojisidir. Son yıllarda gelişen görüntüleme teknikleriyle beraber, lomber disk hernisi, semptomatik olmayan olgularda da saptanabilmektedir. ${ }^{[4]}$
Lumbar disc herniation is one of the common causes of back pain. Symptoms occurs according to nerve root, which effected by herniated disc. Lumbar disc herniation is diagnosed by clinical symptoms and findings that are supported by radiological imaging. Although the operative treatment results seem significantly better than conservative treatment in earlier terms, late term results are quite similar. For every patient, the most suitable treatment method with surgical or non-surgical options, must be evaluated carefully and individually.

Key words: lumbar disc herniation; back pain; discectomy

\section{PATOANATOMI}

\section{Disk Anatomisi}

İntervertebral diski anatomisine bakılacak olursa; iki end plate arasında, ortada yarı sıvı kıvamında nükleus pulpozus etrafinda lamellar şeklinde uzanan kollejen liflerden oluşan anulus fibrozustan oluşmaktadır. Von Luscka, yapısı göz önünde bulundurulduğunda, bu alanı diartroz tipi ekleme benzetmiş; her iki end plate'i artiküler yüzler; anulus fibrozusu eklem kapsülü; nükleusu ise, içindeki sıvılla beraber sinoviya ve eklem boşluğu olarak tanımlamıştır. ${ }^{[5]}$

End plate, nükleus pulpozus ve anulus fibrozus kapalı bir sistem olarak çalışmaktadır. nükleusa gelen kompresif yükler sıkışan ve düzleşen nükleus tarafından tensil kuwvet olarak anulus lamellerine transfer edilir. ${ }^{[6]}$

Disk, iki vertebra arasında faset eklem hizasında, spinal kanalın ön bölümünü oluşturur. Bu alan, posterior longitudinal bağ tarafından kaplanır; bu bağ orta hatta son derece kalınken, laterale doğru incelerek

- İletişim adresi: Op. Dr. Seçkin Sarı, Ortopedi ve Travmatoloji Uzmanı, Memorial Hizmet Hastanesi, Güneş Sok. No: 2-4, Bahçelievler, İstanbul Tel: 0505 - 8965939 e-posta: drssari@gmail.com

- Geliş tarihi: 17 Ağustos 2015 Kabul tarihi: 17 Ağustos 2015 


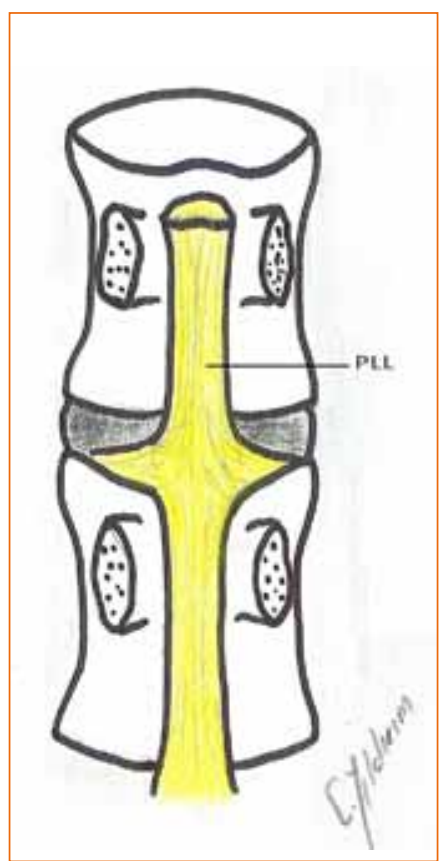

Şekil 1. Posterior longitudinal bağ (PLL).

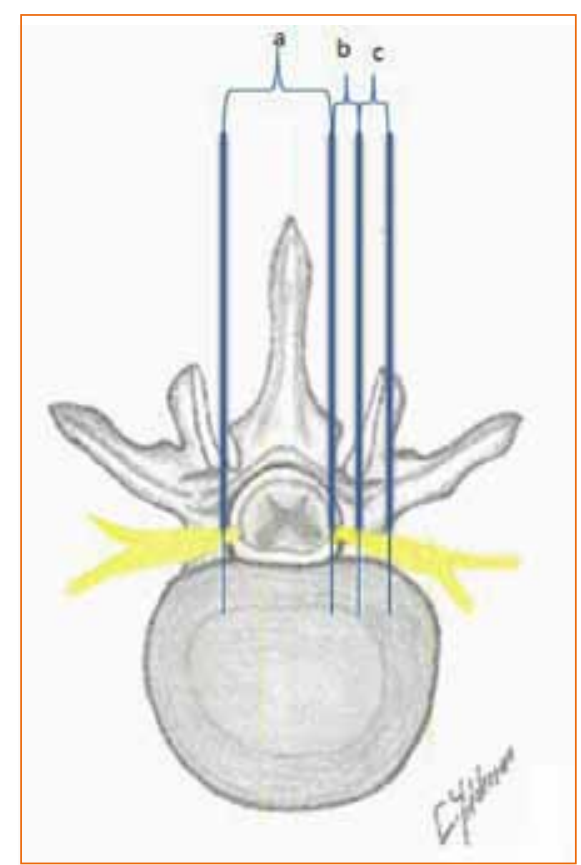

Şekil 2. a-c. Santral bölge (a); lateral reses (posterolateral bölge) (b); foraminal bölge (c).

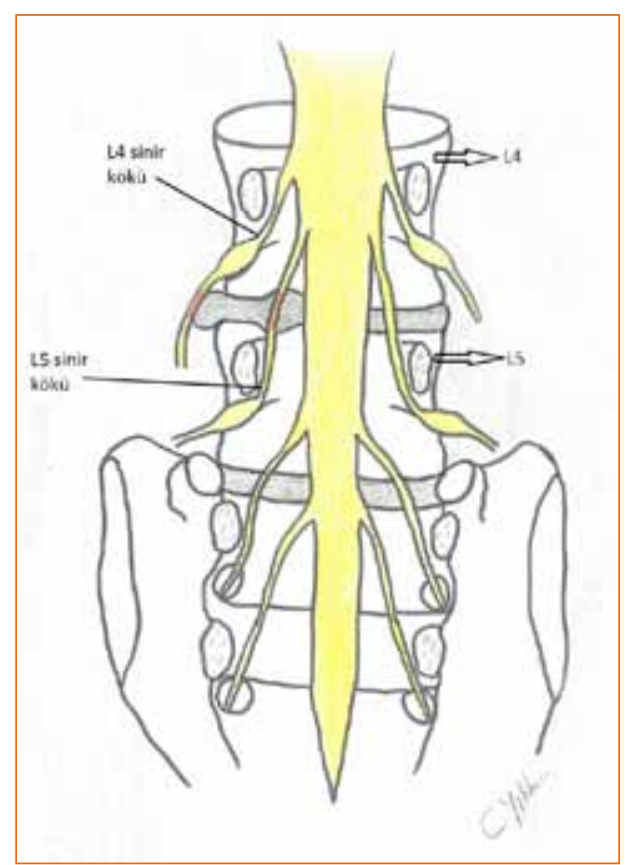

Şekil 3. L4-L5 diskinden kaynaklanan herni, lateral reseste L5 köküne basarken, ekstraforaminal ise L4 köküne basar. ilerler ve diskin inferolateralini kaplar. Bu dağılım sonucu, diskin posterolaterali boş kalmaktadır. Bu nedenle, bu bölge disk hernilerinin en sık görüldüğü alandır (Şekil 1).

L1-L2 hizasında sonlanan spinal kord, kauda ekina olarak devam eder. Kökler, bu seviyeden sonra, çıktıkları foramenin bir üst seviyesinde kaudadan ayrılır. Örneğin; L5 kökü, L4 korpus hizasında dural keseden ayrılarak, aşağıya doğru lateralize olarak devam eder ve L5 forameninde çıkar. Bu anatomik durum göz önünde bulundurulduğunda, herniye olan diskin kanal içindeki yeri, bası altındaki kökü belirlemede yardımcı olur; bundan dolayı, spinal kanal longitudinal olarak bölgelere ayrılmıştır. Bu bölgeler; santral, lateral reses, foraminal ve ekstraforaminal şeklindedir (Şekil 2).

L4-L5 diskinden kaynaklanan herni, lateral reseste L5 köküne basarken, ekstraforaminal ise L4 köküne basar (Şekil 3).

\section{Patofizyoloji}

Disk herniyasyonu, sıklıkla dejenerasyon sürecindeki patolojilerden biridir. Bu, özellikle torsiyonel kuvetlere dayanamayan anulus fibrillerinin yırtılması ve bunun sonucu kapalı bir sistem olarak çalışan end plate-nükleus-anulus kompleksinin devre dışı kalması ve gelen kompresif kuvvetin etkisiyle nükleusun yırtık anulus bölgesinden herniye olması şeklindedir.
Nükleus, notokord artığı olması nedeniyle, vücut için antijeniktir. Herniye olan nükleusa karşı başlayan immünolojik reaksiyon, sinir kökündeki inflamasyonu arttırmakta ve bası etkisiyle birlikte şiddetli radiküler bulgulara neden olmaktadır. Bu durum, lomber disk hernisindeki klinik tablonun, periferik tuzak nöropatilere göre daha şiddetli ve erken başlamasına neden olmaktadır. Nükleus ne kadar intakt ve sıvı formundaysa, o kadar kolay herniye olur. Bu nedenle, semptomatik lomber herniler genç yetişkinlerde daha sık görülür. ${ }^{[7]}$

Birincil olarak, patoloji anulusun yırtılmaya başlamasıyla ortaya çıksa da, bir diğer süreç; gelen kompresif yüke bağlı gelişen end plate kırı̆̆ı ve verbra korpusundaki spongiyöz kemik ve kan elemanlarıyla temas eden nükleusa yönelik bir immün reaksiyon başlaması ve nükleusun rezolüye olarak disk mesafesinin daralması, dolayısıyla gelen bütün yükü almak zorunda kalan anulusun, kanala doğru migre olarak, kanal darlığına veya kök basısına neden olmasıdır. Oluşan bu bası, radiküler ağrıyla birlikte kliniğin oturmasının sağlar.

Sıklık göz önünde bulundurulduğunda, seviyenin mobilitesi herni görülme riskini arttırmaktadır. Bundan dolayı, en fazla disk hernisi görülen seviye, en mobil olan L4-5 ve L5-S1 (\%95) seviyeleridir. Ardından, L3-4 ve proksimale doğru azalarak devam etmektedir. ${ }^{[8]}$ 


\section{Sinıflama}

Lomber disk hernisi üç alt başlıkta sınıflandırılmıştır:[9]

1) Protrude disk hernisi: eksentrik taşma mevcuttur; anulusu sağlamdır.

2) Ekstrude disk hernisi: nükleus yırtık anulusu geçmiştir; ancak, hala disk aralığındaki nükleus gövdesiyle bağlantısı vardır.

3) Sekestre disk hernisi: Artık parça disk aralığı ile bağlantısı yitirmiştir ve serbest fragman halindedir.

Bunların dışında, ekstrude diskin son anullar lamella tarafindan sarılması dumuna, devamlı (continued); sarılı olmaması durumuna göre ise devamlı olmayan (uncontinued) olarak isimlendirilir. Bu durumda disk içine verilen sıvı, fragmanın en dışındaki anüler yapı intakt (devamlı) ise spinal kanala sızmaz.

Ekstrude diskin posterior longitudinal bağla olan ilişkisine göre; subligamentöz, ekstraligamentöz, transligamentöz, perfore, subkapsüler, veya submembranöz olarak adlandırılırlar.

\section{KLINIK VE SEMPTOMLAR}

Hastaların kliniği, basının fazlalığına ve etkilenen sinir köküne göre değişiklik gösterse de, çoğunda daha önceden bel ağrısı mevcuttur. Bu ağrı, sıklıkla çok rahatsız etmeyen ve uzun süre ayakta kalmakla artan şekildedir. Tablonun aniden kötüleşmesi, bir travma, ani hareket (özellikle rotasyonel) veya ağır kaldırmaya bağı olabildiği gibi, her hangi bir neden olmaksızın ani başlayan radiküler ağrı da ortaya çıkabilir. Suri ve arkadaşlarının yaptığı ileriye dönük bir çalışmada, yeni tanı almış 154 hasta değerlendirildiğinde, hastaların \%62'si neden olmaksızın başlayan bacak ağrısı tanımlamışlardır. ${ }^{[10]}$

Bası altında olan kökler L5 veya S1 ise, dermatomal farklılıklar olsa da, ön planda siyataljik yakınmalar mevcuttur. Kas gücü kaybı, ayak ve ayak bileği düzeyinde değerlendirilir. L2, L3 ve L4 köklerine olan basılarda ise, hastada daha çok, femoral sinir trasesinde, uylukta lokalize ağrı, kuadrisepste güçsüzlük, dizde boşalma hissi ön plandadır.

Hastanın değerlendirilmesi, dermatom ve kas gücü değerlendirilmesini, tendon reflekslerini içermelidir. L4-L5-S1 köklerinin değerlendirilmesi için, düz bacak kaldırma ve bu testin modifikasyonu olan Laseque testi gibi provaktif sinir germe testleri, L2 ve L3 kökleri için femoral germe testi yapılmalıdır. Özellikle düz bacak kaldırma testi, lomber disk hernisi tanısı için çok değerli bir yöntemdir. Düz bacak kaldırma testinin pozitifliği durumunda, kök basısı olma oranı $\% 90$ olarak bulunmuştur. ${ }^{[11]}$

\section{RADYOLOJi}

\section{Düz Grafi}

Düz grafiler, öncelikle akut travma durumlarında yardımcı olur. Bunun dışında, dejeneratif değişikliklerin saptanması, deformitenin varlığı ve kronik olgularda artma olup olmadığı, instabilite (spondilolistezis), lumbalizasyon (özellikle cerrahi plan varsa) araştırılması ve spina bifida occulta gibi durumlarda yardımcıdır. Ancak, lomber disk hernisi ile ilgili direkt bilgi vermez.

\section{Miyelografi}

Miyelografi, geçmişte disk hernisi tanısı için yaygın olarak kullanılmıştır; lomber subaraknoid mesafeye kontrast madde enjeksiyonu yapılarak çekilen düz grafilerdir. Dinamik ve ayakta çekimler yapılabilmesi, büyük avantaj sağlamaktadır. Ancak, beyin omurilik sıvısı (BOS) dolaşımının olmadığı foraminal ve ekstraforaminal bölge, miyelografi ile değerlendirilememektedir. Miyelografinin, araknoidit, menenjit ve kontrast madde alerjisi gibi komplikasyonları olması nedeniyle, bilgisayarlı tomografi (BT) ve manyetik rezonans (MR) görüntüleme tekniklerinin gelişmesiyle birlikte, kullanımı giderek azalmıştır.

\section{BT}

Özellikle mesafe, kanal, faset eklemlerindeki dejeneratif değişikliklerin değerlendirilmesinde, kemik çerçeve ve foramenin gösterilmesinde kullanışlıdır. Gerekli durumlarda (MR çekimi yapılamayan hastalarda) alınan yumuşak yoğunluklu kesitler, herniye diski gösterebilmektedir. Özellikle revizyon olgularında, miyelografi ile kombine kullanımı (miyelo-BT) oldukça bilgilendiricidir.

\section{MR}

$M R$, günümüzde lomber disk hernisi tanısı için en değerli yöntemdir; disk hernisi yeri, fragmanın tipi, eşlik eden yumuşak doku patolojileri, radikülit, faset eklemlerin durumu, sinovit, foraminal ve ekstraforaminal alan hakkında bilgi verir. Kontrastlı sekanslar ve miyelografi ile cerrahi sonrası değişikliklerin nüksten ayrılması ve kanal darlığının gösterilmesinde yardımcıdır.

\section{TEDAVi}

\section{Konservatif Tedavi}

Fizyoterapi, konservatif tedavinin, medikal tedaviyle birlikte ilk basamağını oluşturur. Kısa süreli (3-4 gün) günlük yaşamsal aktiviteler (mutad iştigal) haricinde, istirahati takiben, özellikle karın kasları, gluteal bölge ve hamstringlere yönelik, güçlendirici ve esnetici olacak 
şekilde egzersizler planlanır. Hastaların eğitilmesi ve özellikle intervertebral disk basıncını arttıracak hareketlerden kaçınmanın öğretilmesi gerekir. Hasta, özellikle torsiyonel streslerden kendini korumalıdır.

Medikal tedavi, fizyoterapi toleransını ve hasta konforu arttıracağı için, eşzamanlı kullanılması önerilmektedir. Öncelikle NSAii, intervertebral alandaki inflamasyon ve ödemi azaltacağı için kullanılır. Olumlu sonuçlarının yanında, gastrointestinal sistem yan etkileri kullanımı kısıtlayabilir. Böyle durumlarda, narkotik analjezikler kullanılmaktadır. Bir diğer medikal ajan, özellikle kas dokusuna direkt etkili miyorelaksanlardır; bunlar, spazmı engelleyerek belirgin semptomatik rahatlama sağlar.

Bir diğer semptomatik tedavi yöntemi, epiduraltransforaminal lokal steroid enjeksiyonlarından oluşmaktadır. Epidural enjeksiyonun, etkisi kısa süreli olmakla ve daha çok bel ağrısına yönelik rahatlama sağlamakla birlikte, lomber disk hernisinde etkinliği çok yüksek değildir. ${ }^{[12]}$ Transforaminal kök enjeksiyonu, özellikle radiküler yakınmaları azaltır. Sıklıkla, konservatif tedavinin ilk basamaklarına cevap vermeyen veya cerrahi tedaviye uygun olmayan ya da cerrahiyi kabul etmeyen hastalarda uygulanabilmektedir. Yapılan çalışmalarda, kısa dönemde yüksek oranlarda olumlu sonuçlar bildirilmektedir.

İntradiskal girişimlerin; nükleoplasti (radyofrekans ile diskin küçültülmesi), intradiskal elektrotermal tedavi (ısı ile diskin küçültülmesi), kemonükleoliz (paparin adlı maddenin disk içine enjekte edilmesi ve diskin rezolüsyonu) gibi yöntemlerin, lomber disk hernisi tedavisinde kullanılmakla beraber, endikasyonlarını darlığı nedeniyle kullanımı kısıtlıdır. Ekstrude disklerde, mesafede \%30'dan fazla daralma varlığında ve anulusun total yırtılmış olması durumunda kullanılamamaktadır. Diskte dejenerasyon sürecini hızlandırdığından, günümüzde sık tercih edilmemektedir.

\section{Cerrahi Tedavi}

Lomber disk hernisinin tedavisinde cerrahi tedavi, hasta düzeyinde tartışılması ve değerlendirilmesi gereken bir tablodur. Lomber disk hernisinin cerrahi tedavisinde mutlak endikasyon olan tek durum, progresif nörolojik defisit ve perineal hipoestezi gayta ve idrar inkontinansıyla giden, kauda ekina sendromu varlığıdır. Bunların dışındaki rölatif endikasyonlarda, cerrah, hastanın mevcut durumunu, semptomları ve fizik muayene bulgularını (pozitif düz bacak kaldırma, uyumlu dermotomda hipoestezi, kas güçsüzlüğü gibi) göz önünde bulundurarak, cerrahi tedavinin mevcut risklerini, hasta için kar/zarar ilişkisi içinde değerlendirerek karar vermelidir. Sonuç olarak, cerrahi tedavinin diğer tedavilere olan en büyük üstünlüğü, erken dönemde hızlı bir şekilde hastanın ağrısının azalmasıdır. Bu nedenle, hem hasta hem de hekim açısından, hastanın ağrı toleransı ve yaşam kalitesi, cerrahi sürece gidiş açısından en önemli yol göstericidir.

\section{MIKROSKOBIK DISKEKTOMi}

Açık diskektomi, lomber disk hernisinde en yaygın kullanılan cerrahi tekniktir. Yapılan laminotomi ve sonrasında, kökün korunmaya alınarak disk fragmanının eksize edilmesi şeklindedir. Mikroskopun 60'lı yıllarda lomber disk cerrahisinde kullanımına girmesiyle beraber, diskektomi daha küçük bir alandan yapılmakta, mevcut magnifikasyonve aydınlatma sayesinde, çevre nöral yapıların korunması daha rahat olarak sağlanmaktadır. Bu çerçevede, cerrahi sonrası komplikasyon oranları da belirgin olarak azalmış ve insizyon- disseksiyonun küçülmesi, cerrahi sonrası rehabilitasyon sürecini kısaltmıştır.

\section{Cerrahi Teknik}

Sıklıkla genel anestezi altında, spinal anestezide tercih edilebilir. Hasta pron pozisyonda yatırılır. Abdomen rahat olacak şekilde, yastıklarla veya hazır spinal çerçeve ile desteklenir. Abdomenin bası altında olmaması, epidural venlerin basıncının düşük olmasını, böylece kanama miktarının daha az ve cerrahi sahanın görüşünün daha kolay olmasını sağlayacaktır. Bu destekle, kalça eklemi fleksiyona gelir ve interlaminar alanın genişlemesi sağlanır. Eğer semptomatik olan fragman küçük ise, kalçanın fleksiyona alınışı fragmanın tespitinde zorluk çıkaracağı için, hastanın kalça ve lomber bölgesi nötralde olacak şekilde yatırılması kolaylık yaratacaktır.

Ardından, floroskopi ile seviye tespiti yapılır. Iliak kanatların superior krestlerini birleştiren çizgi, L4-5 diski veya L3-4 spinöz çıkıntısı hizasındadır. Floroskopi eşliğinde yapılan seviye tespiti sonrası, temizlik ve örtüm yapılır. Ardından, cilt insize edilir. Cilt altı doku geçilir ve spinöz çıkıntıya yakın olacak şekilde, kaslar koter yardımıyla laminaya doğru sıyrılır. Bu işlem, periost elevatörü veya Cobb elevatör yardımı ile sıyrılarak da yapılabilir. Ardından, interlaminar alan faset ekleme kadar ortaya konur; bu aşamada, faset eklemin kapsülünün hasar görmemesine dikkat etmek gerekir. Cerrahi sahanın açıklığını sağlamak için, Taylor veya Wiliams ekartör kullanılabilir. Sıklıkla kullanılan, Taylor ekartördür. Biz de cerrahi pratiğimizde Taylor ekartör kullanmaktayız. Taylor ekartör, ucu faset eklem lateraline dayanacak şekilde yerleştirilir. Bu aşamada, ekatörü ucuna bağlayan sargı aşağı doğru sarkıtılarak, ucuna bir litre sıvı asılır ve tekrar seviye tespiti 


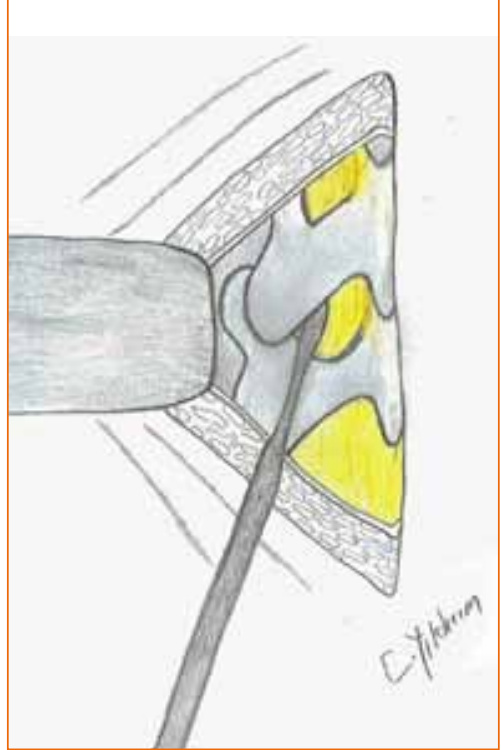

Şekil 4. Ligamentum flavum'un gevşetilmesi.

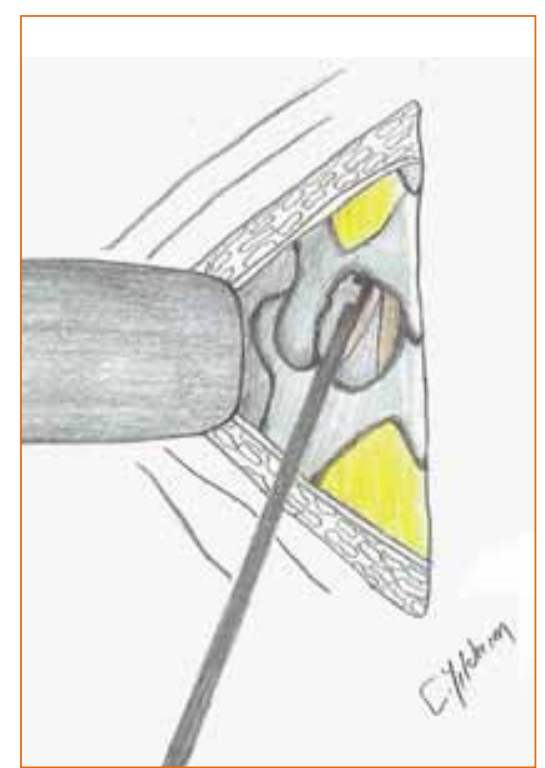

Şekil 5. Laminektomi.

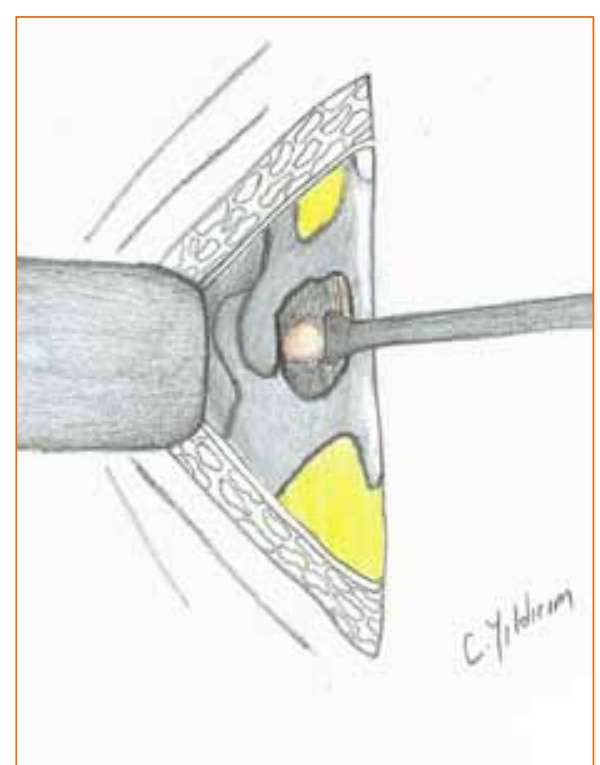

Şekil 6. Diskektomi. yapılır. Ardından, lamina etrafındaki yumuşak dokular rongeur veya küret yardımıyla temizlenir. Laminatomi yapılacak alan, rongeur yardımıyla inceltilir. Ardından, mikroskop cerrahın karşısından yaklaşacak şekilde alınır. Dissektör yardımıyla, lamina altında ligamentum flavum sıyrılır ve gevşetilmeye çalışılır (Şekil 4).

Lamina, ligamentum flavum aksı boyunca kraniyale doğru kerison ile yenmeye başlanır. Ligamentum falvum'un serbestleştiği alandan itibaren, laterale doğru laminotomi genişletilir (Şekil 5).

Laminotomi ile açılan spongiyöz kemikten kanama, kemik uçlarına konan kemik mumu yardımıyla engellenir. Ardından, serbest ligamentum flavum, dura ve kök görünene kadar eksize edilir. Bu sırada oluşacak kanamalar, bipolar koter ve ipli pamuk yardımı ile kontrol altına alınır. Ardından, kök mediyale ekarte edilerek, disk fragmanı ortaya konur (Şekil 6).

Künt bir alet ile, disk olduğu düşündüğümüz yapıya vurarak kök olmadığını son defa kontrol ettikten sonra, 15 numara bistüri yardımıyla anülotomi yapılır ve fragman, hipofiz punch yardımıyla eksize edilir. Kanalın ve kökün rahat olup olmadığı, hook yardımıyla kontrol edilir. Ardından, anülotomi sahası serum fizyolojik ile yıkanarak, serbest fragmanların saptanması ve temizlenmesi sağlanır. Kanama kontrolü yapıldıktan sonra, fasya ve tüm katlar dikkatlice kapatılır. Herhangi bir dren koymaya gerek yoktur. Rutin korse kullanımı cerrahi sonrası gerekmez. Üç hafta yatak istirahati ve efor kısıtlaması yeterlidir.

\section{FAR LATERAL - EKSTRAFORAMINAL DISK HERNISI}

Sıklıkla yaşlı hastalarda görülen, saptandığı seviyede inen köke değil çıkan köke bası olduğu için herni seviyesindeki köke ait radiküler semptomlar veren, lomber disk hernisidir.

Tedavisinde değişik teknikler kullanılır. Laminektomi ve parsiyel fasetektomi sonrası kökün mediyalden itibaren takip edilmesi ve bası seviyesinin bulunduktan sonra diskektomi yapılması, uygulanan tekniklerden biridir. Bu teknikte, fasetektomi yapıldığından, instabilite riski vardır. Ancak, Garrido ve arkadaşları bu teknikte, 35 hastanın birinde radyolojik instabilite bildirmektedir. ${ }^{[13]}$ Bir diğer teknik, Donaldson tarafından tanımlanmıştır. Donaldson, transvers çıkıntıların etrafını açıp, ardından yapılan hemilaminektomi ile kökü bir prob yardımıyla mediyalden laterale takip ederek fasete dokunmadan kökün lateralde bulunması ve ardından diskektomi yapılmasını tanımlamış ve bu teknikle $\% 72$ olumlu sonuç olduğunu ve hiç instabilite olmadığını bildirmiştir. ${ }^{[14]}$

Bir diğer yöntem, tarafımızca da rutin olarak klinikte uygulanmakta olan, Wiltse'nin paraspinal girişimi kullanılıp, transvers proses aralığından kökün disseke edilerek diskektomi yapılmasıdır. Bu teknikle, $\% 85$ olumlu sonuç bildiren çalışmalar mevcuttur. ${ }^{[15]}$ Günümüzde, far lateral-ekstraforaminal diks hernilerinde genel cerrahi yaklaşım, intertransvers aralıktan Wiltse paraspinal girişimi ile yapılmaktadır. 


\section{ENDOSKOPIK DISKEKTOMI}

Cerrahi ekipmanların gelişmesiyle uygulanmaya başlayan bir yöntemdir. Skopi kontrolünde mesafe saptanması sonrasında, dilatatör ve ekartörler yerleştirilerek, endoskop yardımıyla yapılan diskektomi şeklidir. Görüşün kısıtlı olması ve yüksek cerrahi tecrübe gerektirmesi, dezavantajlarıdır ve sonuçlarına bakılacak olursa, açık mikro-diskektomiden farkı olmaması, yaygınlaşmamasının başlıca nedenleridir. ${ }^{[16]}$

\section{TRANSFORAMINAL ENDOSKOPIK DISKEKTOMI}

Genel olarak, far lateral veya foraminal diks hernilerinin tedavisinde kullanılmaktadır. Ancak, deneyimli cerrahlar, orta hat disk hernilerinde de kullanmaktadırlar. Far lateral ve foraminal disklerde açık cerrahiye göre disseksiyon yapılmaması ve sıklıkla kemik müdahalesi gerektirmemesi nedeniyle, cerrahi sonrası morbiditesi açısından, açık cerrahiye göre belirgin olarak daha üstün bir tekniktir. L5-S1 seviyesinde giriş sahasına giren iliak kanatlar nedeniyle, yaklaşım ve girişim olukça zorlaşmakta ve rijid endoskoplar kullanılamamaktadır. Bu seviyede işlem, ancak fleksible endokopların varlığında yapılabilmektedir. Ancak, bu seviye üzerinde, L3-4 ve L4-5 seviyesinde kolaylıkla uygulanabilir.

\section{CERRAHI VE KONSERVATIF TEDAVi}

Cerrahi ve konservatif tedavi sonuçlarını değerlendiren, birçok randomize kontrollü çalışma mevcuttur. Hastalığın takibinde, gelişen gruplar arası değişimler; "konservatif gruptan hastaların takipler sırasında opere olması veya operasyon hazırlığ sırasında cerrahi müdahaleden vazgeçen veya verilen konservatif tedavilerden aldığı sonuçlarla operasyondan vazgeçen hastalar" bu çalışmalardaki ana çeldiricilerdir.

Bu çalışmaların en eskisi Weber tarafından yapılmış ve yazar, cerrahi-konservatif endikasyonu belli grupların dışında, endikasyonu kesin olmayan 126 hastayı değerlendirmiştir. Başlangıçta, cerrahi grup sonuçları belirgin olarak daha iyi iken ( $\% 65$ 'e \%33), on yılın sonunda gruplar arasında istatistiksel fark olmadığı görülmektedir. ${ }^{[17]}$ Osterma, yaptığı iki yıllık takip sonuçlarında, cerrahi grup ile konservatif grup arasında fark olmadığını belirtmiş; ancak alt grup olarak değerlendirildiğinde, L4-L5 diskinden kaynaklanan hernilerde, cerrahi sonucun daha başarılı olduğunu bildirmiştir. ${ }^{[18]}$ Beş yüzden fazla hastayı içeren Maine Lumbar Spine Study (MLSS) çalışmasında, başlangıçta cerrahi grubun \%71'e \%43 oranında konservatif gruba göre sonuçları iyi iken, geçen sürelerde aradaki fark konservatif grup lehine değişmiştir. Onuncu yıl sonuçlarında, istatistiksel fark bulunmamıştır. Ancak, çalışma sırasında gruplar arasındaki değişim her iki grup için yaklaşık \%25 oranında olmuştur. İyi sonuç kriterlerinde "hiç ağıım kalmadı" "başlangıca göre iyi" cevapları, aynı seviyede iyileşme olarak değerlendirilmiştir. Alt grup olarak bakıldığında ise, cerrahi uygulanan grubun cevapları belirgin olarak konservatif gruptan iyi olarak saptanmıştır. [19-21]

Son yıllarda yapılmış en fazla hasta sayısına sahip randomize kontrollü çalışma, Spine Patient Outcome Research Trial (SPORT) çalışmasıdır. Bu çalışmada, cerrahi seçenek olarak mikrodiskektomi uygulanırken, konservatif grupta çoğu hastada epidural steroid enjeksiyonları ve narkotik analjezikler de kullanılmıştır. Çalışmanın ikinci yıl sonuçlarına bakıldığında, diğer çalışmalara benzer olarak, cerrahi grup belirgin olarak iyi sonuçlar elde edilmiştir; ancak, bu çalışmada gruplar arası değişim, cerrahiden konservatife \%40 konservatiften cerrahiye $\% 45$ olarak saptanmıştır. Dördüncü yıldaki değerlendirmelerde, cerrahi grup belirgin oranda daha iyi sonuca sahipken, MLSS'den farklı olarak, iki grup arasındaki fark azalmamıştır. Ancak, bu çalışmadaki gruplar arasındaki değişimler, randomizasyon kriterini devre dışı bırakarak, çalışmanın değerini düşürmüştür. ${ }^{[22-24]}$

Sonuç olarak bakıldığında, tüm çalışmalarda, cerrahi uygulanan hastaların erken dönem sonuçları iyi olsa $\mathrm{da}$, işe dönüş zamanları ve çalışabilirlikleri arasında istatistiksel olarak fark yoktur. Gruplar arasındaki, özellikle cerrahi gruptan konservatif gruba geçen hastalar, "en yüksek oran SPORT çalışmasında" değerlendirildiğinde, cerrahi endikasyonu olan kişi kontrollü bir şekilde mevcut semptomları tolere edebilirse ve tedavisine cerrahi dışı seçeneklerle devam etmek isterse, şikayetler tolere edilebilir bir düzeye gelebilmektedir.

Bu sonuçların ışığında, lomber disk herni tanısı almış radiküler semptomları olan hastaların her biri ayrı olarak değerlendirilmeli ve her iki tedavi seçeneği de, riskleri ve sonuçlarıyla, hastalara sunulmalıdır. ${ }^{[24]}$

\section{ÇIKARIMLAR}

Bel ağrısı, en sık hekime başvuru nedenleri arasında yer almaktadır. Bel ağrısının nedenleri arasında ise büyük bir yeri olan, disk dejenerasyonu ve disk hernisi, toplum sağlığı açısından önemini korumaktadır. Dejenere diskin rejenerasyonu ile ilgili birçok deneysel çalışma bulunsa da, bunlardan hiçbiri, şu anda klinik kullanımda kanıta dayalı değeri yüksek sonuçlarla yer almamaktadır. Fakat, bu yönde yapılan deneysel çalışmalara her gün yenileri eklenmektedir. Ayrıca, hasta popülasyonunun büyüklüğü, endüstriyi bu konuya daha fazla yoğunlaştırmaktadır. 
Herniye olmuş diskin tedavisinde ise, diskektomi halen en popüler yöntem olmaya devam etmektedir. Diskektomi, ister uzun zamandır kullanılan standart teknikler isterse de minimal invaziv teknikler olsun, diskin çıktığı ve bizim de mesafeyi boşaltırken kullandığımız anüller defektin tamirinde yetersiz kalmaktadır. Literatürde, birçok çalışma ile anullus tamiri yapılmaya kalkılmış olsa da, henüz yaygınlaşmış başarılı sonuçları ile adını duyuran bir anüler tamir yöntemi bulunmamaktadır.

Gelecekte, dejenere diskin rejenerasyonu ve anüler tamir konusunda birçok çalışma ve yeniliklere ihtiyaç duyulmaktadır. Diskin dejenerasyon mekanizmasının daha iyi anlaşılmasının, bu alanda yapılacak gelişmelere önemli ışık tutacağı kanısındayız.

\section{KAYNAKLAR}

1. Hermenau S, Grauger JN. The evaluation and management of axial neck and low back pain. In: Rao R, Smuck M, editors. Orthopedic Knowledge Update. Spine 4, Chapter 25. Madrid, España: AAOS; 2012. p.283-92.

2. Andersson GB. Epidemiological features of chronic low back pain. Lancet 1999;354(9178):581-5. CrossRef

3. Andersson GB, Biyani A, Eriksen S. Lumbar disc disease. In: Herkowitz HN, Garfin SR, Eismont FJ, Bell GR, Balderston R, editors. Rothman-Simeone The Spine 6th ed. Chapter 45. Canada: Saunders Elsevier; 2011. p.846-7.

4. Boden SD, Davis DO, DinaTS, Patronas NJ, Wiesel SW. Abnormal magnetic-resonance scans of the lumbar spine in asymptomatic subjects. A prospective investigation. J Bone Joint Surg Am 1990;72(3):403-8.

5. Shapiro MI, Risbud MV. Introduction to the structure, function, and comparative anatomy of the vertebrae and the intervertebral disc. In: Shapiro MI, Risbud MV, editors. The intervertebral disc. Chapter 1. Vienna: Springer-Verlag; 2013. p.3-15.

6. Panjabi MM, Agustus A. Clinical Biomechanics of the Spine, 2nd ed. Philadelphia: Lipincott-Raven; 1990.

7. Bono CM, Schoenfeld A, Garfin SR. Lumbar disc herniations. In: Rao R, Smuck M, editors. Orthopedic Knowledge Update. Spine 4, Chapter 46. Madrid, España: AAOS; 2012. p.887-913.

8. Postacchini F, Postacchini R. Operative management of lumbar disc herniation: the evolution of knowledge and surgical techniques in the last century. Acta Neurochir Suppl 2011;108:17-21. CrossRef

9. Spengler DM, Ouellette EA, Battié M, Zeh J. Elective discectomy for herniation of a lumbar disc. Additional experience with an objective method. J Bone Joint Surg Am 1990;72(2):230-7.

10. Suri P, Hunter DJ, Joueve C, Hartigan C, Limke J, Pena E, Swaim B, Li L, Rainville J. Inciting events associated with lumbar disc herniation. Spine J 2010;10(5):388-95. CrossRef
11. Kosteljanetz M, Espersen JO, Halaburt $H$, Miletic $T$. Predictive value of clinical and surgical findings in patients with lumbago-sciatica. A prospective study (Part 1). Acta Neurochir (Wien) 1984;73(1-2):67-76.

12. Staal JB, de Bie RA, de Vet HC, Hildebrant J, Nelemans $P$. Injection therapy for subacute and chronic low back pain: an updated Cochrane review. Spine (Phila Pa 1976) 2009;34(1):49-59. CrossRef

13. Garrido E, Connaughton PN. Unilateral facetectomy approach for lateral lumbar disc herniation. J Neurosurg 1991;74(5):754-6.

14. Donaldson WF 3rd, Star MJ, Thorne RP. Surgical treatment for the lateral herniated lumbar disc. Spine (Phila Pa 1976) 1993;18(10):1263-7.

15. Weiner BK, Dabbah M. Lateral lumbar disc treated with a paraspinal approach: an independent assessment of longerterm outcomes. J Spinal Disord Tech 2005;18(6):519-21.

16. Yeung AT, Yeung CA. Minimally invasive techniques for the management of lumbar disc herniation. Orthop Clin North Am 2007;38(3):363-72.

17. Weber $\mathrm{H}$. Lumbar disc herniation. A controlled, prospective study with ten years of observation. Spine (Phila Pa 1976) 1983;8(2):131-40.

18. Osterman $H$, Seitsalo $S$, Karppinen J, Malmivaara A. Effectiveness of microdiscectomy for lumbar disc herniation: a randomized controlled trial with 2 years of follow-up. Spine (Phila Pa 1976) 2006;31(21):2409-14.

19. Atlas SJ, Deyo RA, Keller RB, Chapin AM, Patrick DL, Long JM, Singer DE. The Maine Lumbar Spine Study, Part II. 1 -year outcomes of surgical and nonsurgical management of sciatica. Spine (Phila Pa 1976) 1996;21(15):1777-86.

20. Atlas SJ, Keller RB, Chang Y, Deyo RA, Singer DE. Surgical and nonsurgical management of sciatica secondary to a lumbar disc herniation: five-year outcomes from the Maine Lumbar Spine Study. Spine (Phila Pa 1976) 2001;26(10):1179-87.

21. Atlas SJ, Keller RB, Wu YA, Deyo RA, Singer DE. Long-term outcomes of surgical and nonsurgical management of sciatica secondary to a lumbar disc herniation: 10 year results from the Maine Lumbar Spine Study. Spine (Phila Pa 1976) 2005;30(8):927-35.

22. Weinstein JN, Lurie JD, Tosteson TD, Skinner JS, Hanscom B, Tosteson AN, Herkowitz H, Fischgrund J, Cammisa FP, Albert T, Deyo RA. Surgical vs nonoperative treatment for lumbar disk herniation. The Spine Patient Outcomes Research Trial (SPORT) observational cohort. JAMA 2006;296(10):2451-9.

23. Weinstein JN, Lurie JD, Tosteson TD, Tosteson AN, Blood EA, Abdu WA, Herkowitz $\mathrm{H}$, Hilibrand A, Albert T, Fischgrund J. Surgical versus nonoperative treatment for lumbar disc herniation: four-year results for the Spine Patient Outcomes Research Trial (SPORT). Spine (Phila Pa 1976) 2008;33(25):2789-800. CrossRef

24. Moschetti W, Pearson MA, Abdu WA. Treatment of lubar disc herniation. An evidence-based review. Seminars in Spine Surgery 2009;21(4):223-9. 